\title{
The Impact of Digitalization on the Initiative Budgeting Processes
}

\author{
Valentina Derbeneva ${ }^{1,2, *}$ Natalia Starodubets ${ }^{1}$
}

\author{
${ }^{1}$ Ural Federal University, Yekaterinburg, Russia \\ ${ }^{2}$ Institute of Economics, Ural Branch of RAS, Yekaterinburg, Russia \\ ${ }^{*}$ Corresponding author. Email: derbeneva_v@bk.ru
}

\begin{abstract}
The digital transformation of interaction between local governments and the population is becoming an increasingly urgent task in the field of public administration. One of the areas where information and communication technologies are being rapidly introduced is the sphere of initiative budgeting. With the development of electronic citizen participation, the requirements for digital tools are becoming more stringent. The purpose of this study is to determine the impact of electronic public participation tools on the development of initiative budgeting in Russia. As a result of the study, no connection was found between the amount of funding for initiative budgeting projects and the level of electronic interaction between the authorities and society, which can be explained by the low level of electronic participation mechanisms implementation in the Russian Federation regions at the moment. A statistical analysis of Internet solutions implementation in Russian Federation regions for 2018 and 2019 showed that there is a gradual increase in Internet tools implementation in the initiative budgeting procedure, but this is not enough to talk about the appearance of information and communication technologies driving force in initiative budgeting. Recommendations are made, the implementation of which will enhance the role of electronic tools of participation in strengthening trust between the authorities and society, which will contribute to the population involvement in initiative budgeting processes.
\end{abstract}

Keywords: Participatory budgeting, Initiative budgeting, Digitalization, E-participation, E-democracy, Egovernment.

\section{INTRODUCTION}

During global digitalization, most public administration processes have been transformed using egovernment services. This includes efforts to create more democratic governance practices, such as e-budgeting.

Digitalization in participatory budgeting (participatory budgeting in Russia received the name of initiative budgeting) refers directly to the concept of eparticipation, which is determined by the use of information and communication technologies to involve the population in the process of making budget decisions. This concept is an integral part of e-government, which can be represented as a complex of organizational, technical, information technology, engineering and auxiliary elements [1]. At the same time, e-participation in budgeting has its own characteristics, which lie in the specifics of the implementation stages of initiative budgeting projects and were described in detail in the author's previous research [2].

The development of initiative budgeting began in Russia in the early 2000s, with the introduction of the Program for the Russian Local Initiatives Support, the main tasks of which were, firstly, to increase the level of access of the population to the socio-economic infrastructure, and secondly, to increase public confidence in government structures through the formation of dialogue and consultation on budgeting of local communities [3].

Some time ago, the very existence of e-participation tools was already considered as a contribution to the initiative budgeting development, but now the mere fact of their availability is no longer enough. The time has come when very specific tasks and requirements are set for electronic instruments. 
In the latest study by the United Nations "EGovernment Survey 2020. Digital Government in the Decade of Action for Sustainable Development" dedicated to the Digital Government, the effectiveness of electronic public participation tools is proposed to be considered in terms of compliance with two requirements. First, compliance with the requirement of availability, which means providing an equal opportunity for all participants in the process to receive information, as well as interact in any convenient for each participant way.

Secondly, compliance with the requirement of evidence, the implementation of which lies in the ability of specific electronic tools to confirm the feasibility of the population's initiatives, to prove the willingness of the authorities to enter dialogue and the desire for interaction. Citizens need to be sure that they will be heard, and their opinion will be considered when allocating the budget. However, the second requirement seems to be impracticable if the government does not ensure equal access to the Internet and does not offer a variety of eparticipation forms. In Figure 1, we disclose the basic requirements for the availability and evidence of online mechanisms for initiative budgeting.
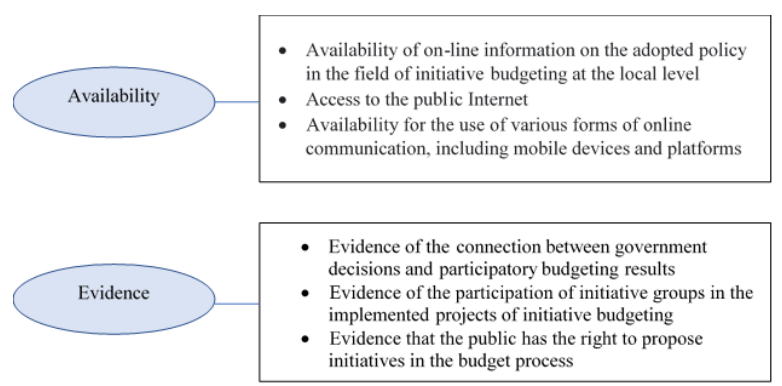

Figure 1 Requirements for e-participatory tools in initiative budgeting

Source: the authors' interpretation based on EGovernment Survey 2020 by UN, retrieved from: https://publicadministration.un.org/egovkb/enus/Reports/UN-E-Government-Survey-2020

So, when implementing availability and evidence requirements, it can be assumed that electronic mechanisms contribute to the development of initiative budgeting.

The main problem on the way to the full implementation of electronic mechanisms in initiative budgeting in Russia was the lack of legislative ability to accept the results of electronic voting for decisionmaking. But in July 2020, the President amended the law on the organization of local government (article 31, Federal Law of 06.10.2003 N 131-FZ "On the general principles of organizing local self-government in the Russian Federation"), which legally approved the possibility of conducting a survey of citizens using information and telecommunication technologies.
In a previous study, the authors assessed the technical readiness of the Russian population for e-participation, as a result of which they found a positive relationship between the availability of the Internet and the quality of the provision of public services [2]. The purpose of this study is to assess the impact of electronic participation tools on the development of initiative budgeting in Russia.

To achieve this goal, the following tasks were set: firstly, to find a correlation between the amount of funds of regional budgets allocated for initiative budgeting and the rating of regions by the quality of public services provision, and secondly, to compare the results with statistical data of The Ministry of Finance of the Russian Federation on the use of electronic mechanisms for public participation, thirdly, to assess the e-participation tools used in practice for compliance with availability and evidence requirements.

\section{THEORETICAL BASIS}

E-participation in the public administration sector has been widely studied by researchers, both by sociologists and economists. Traditionally, close attention is paid to the study of the main motivators that stimulate public participation, as well as the actions of the authorities to involve society in the management process. Thus, Naranjo-Zolotov introduced the concept of virtual community sense and proved that it tends to positively influence the intention of the population to constantly participate in the processes of discussion and decisionmaking at the local level $[4,5]$.

In an empirical study, Sampaio [6] concluded that the voting results of most participatory budgeting electronic platforms are not directly considered when making decisions, but are used only to consider proposals and requests of citizens (electronic requests). In a subsequent paper, the author expanded on this finding by conducting a large-scale survey of participatory budgeting participants at Belo Horizonte in Brazil, where public participation in budgeting in 2008-2011 was entirely electronic [7].

As a result, it was revealed that the majority of citizens were disappointed in the e-participation and the level of trust in the authorities significantly decreased due to the fact that not all decisions made by the public were implemented, and local governments did not always react to the opinion of the population. This once again confirms the importance of the proof factors of public participation, which we discussed above.

Muthomi and Thurmaier [8] offer suggestions on how public participation in government budgeting can be increased, the authors reaffirm the importance of citizens using text messages via social media. An important factor, according to the authors, is the satisfaction of participants with the work of online platforms [9]. 
However, recent studies show e-participation in budget processes is still assessed as relatively low and correlates with a low level of the general population participation. Mærøe, Norta, Tsap and Pappel [10] suggest that increased government funding for eparticipatory budgeting projects will lead to more participants in the future, including increasing the importance of e-participation.

The Russian practice of e-platforms for public participation was studied by E. Kapoguzov and S. Revyakin [11], and the authors concluded that the functionality of the platforms does not allow citizens to influence the topics of the discussed issues and alternatives for voting, which is associated with the early stage of electronic solutions implementation in public administration in Russia. The authors argue that public participation platforms are more about technologies, but not an independent institution that provides fundamental changes in the procedures for interaction between the state and citizens [11].

Most of the Russian studies on initiative budgeting are aimed at studying its details in individual regions, without highlighting the importance of specific participation tools $[12,13]$. Recently, publications on the topic of cause and effect have begun to appear. For example, Gavrilova tried to find the relationship between the types of projects and co-financing [14].

In our previous study, we examined in detail the tools used for electronic participation of citizens in initiative budgeting, highlighting a number of promising tools, including online voting using blockchain technologies, and also revealed a high degree of Russian regions population readiness to interact with government agencies through online mechanisms [2]. At the same time, the question of electronic tools influence on the development of initiative budgeting in Russian regions remains open.

\section{METHOD AND DATA}

In the study authors used graphical and tabular methods of descriptive statistics. Authors suggest to use the amount of regional subsidies for initiative budgeting as an indicator of the initiative budgeting development, since in Russian practice regional budgets are the main source of initiative budgeting financing.

The indicator of digitalization was based on the rating of regions in terms of electronic services provision quality. This indicator is annually calculated by the Ministry of Economic Development of Russia based on monitoring results and is presented on a 100-point scale (retrieved from: https://d-russia.ru/rejting-regionov-pokachestvu-predostavlenija-jelektronnyh-gosuslug.html).

This indicator, according to the authors, is the most relevant for assessing the level of digitalization for the purpose of this article, since it reflects not only the population's access to electronic services, but also the degree of electronic interaction between the population and the government.

For a graphical interpretation, a scatter diagram was used, which presents data on regions distribution by the quality of public services provision and the volume of regional subsidies for the initiative budgeting implementation.

At the second stage, based on a statistical analysis of the Internet solutions implementation and the growth rates of their implementation in Russian regions in 2018 and 2019, the authors assessed the significance of electronic participation procedures in the total set of other forms of participation. At the third stage, authors analyzed the compliance of the electronic participation mechanisms operating in the Russian regions with the requirements of availability and evidence.

For calculations and analytical conclusions, data on the amount of funding and other features of the initiative budgeting implementation in 52 regions were used, which were obtained from the official websites of regional administrations and specialized platforms for initiative budgeting, as well as from the Report on the best practices for initiative budgeting development prepared by the Ministry of Finance of the Russian Federation (retrieved from: https://cutt.ly/LhRChMk).

\section{RESULTS}

\subsection{Assessment of the impact of digitalization in public participation procedures on the initiative budgeting development}

Initiative budgeting has been developing in Russia for over 15 years, but the adaptation of this mechanism across regions is extremely uneven (Fig. 2). The accelerated expansion of initiative budgeting into the regions has been noted in the last two years, with the introduction of clauses in federal legislation to support local initiatives (e.g. Concept for improving the efficiency of budget expenditures in 2019 - 2024, available at http://government.ru/docs/35598/). 


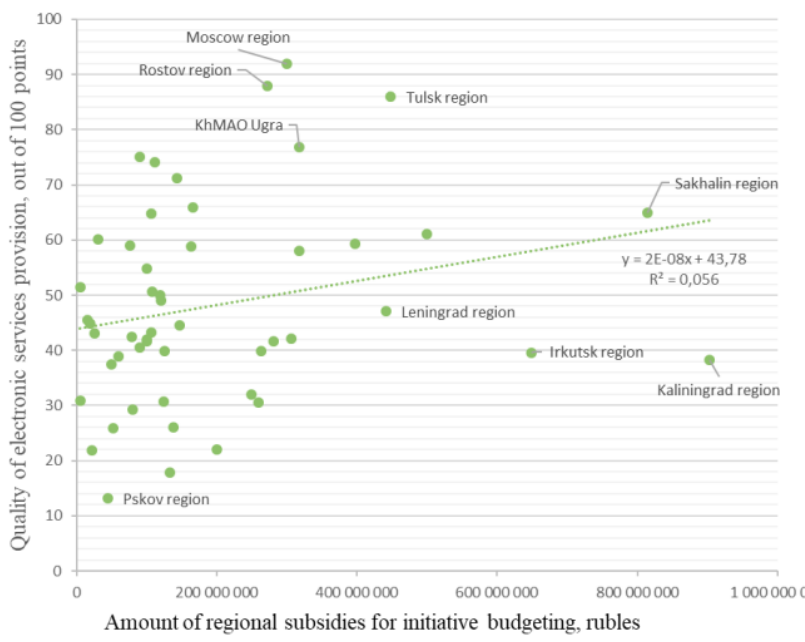

Figure 2 Regions distribution by the volume of regional subsidies for initiative budgeting and the quality of public services provision in 2019

Source: Authors calculations based on Statistical data of Ministry of Economic Development and Ministry of Finance

The scatter diagram shows that the volume of subsidies to regional budgets for initiative budgeting for most of the regions does not exceed 350 million rubles per year, while the quality of the public services provision varies in a wide range from 20 to 75 points on a 100 point scale. The graphic interpretation allows confirming the lack of connection between the provision of electronic public services and regional financing of initiative budgeting.

The obtained results are supported by the data of the Initiative Budgeting Center of the Ministry of Finance, which annually monitor the regions for the initiative budgeting development, and also highlight the best practices in the regions. According to it, Internet solutions are used in $33 \%$ of regions at some stage, implementing the practice of initiative budgeting (Report on the best practices for initiative budgeting development, 2020). From 2018 to 2019, the growth rate of regions implementing online applications increased by $11 \%$ (Table 1)

At the same time, there is a decrease in the practice of using boxes for collecting ideas $(83 \%)$ and questionnaires (92\%), which indirectly reflects the potential of Internet tools as the most technologically advanced method of communication. The growth rate of regions using Internet voting remained practically the same and amounted to $107 \%$. At the same time, the number of regions using citizens' commissions for the selection of projects has significantly increased (167\%), which indirectly reflects the imperfection of the online voting system at the moment.
Table 1. Proposal collection procedures and project selection mechanisms used

\begin{tabular}{|c|c|c|c|}
\hline \multirow[t]{2}{*}{$\begin{array}{r}\text { Initiative } \\
\text { characteristics }\end{array}$} & \multicolumn{2}{|c|}{ rate, \% } & $\begin{array}{l}\text { The } \\
\text { growth } \\
\text { rate, \% }\end{array}$ \\
\hline & 2018 & 2019 & \\
\hline \multicolumn{4}{|c|}{ Proposal collection procedures used } \\
\hline $\begin{array}{l}\text { Face-to-face meetings } \\
\text { and discussions of citizens }\end{array}$ & 52 & 53 & 102 \\
\hline Questionnaire & 33 & 30 & 91 \\
\hline Another mechanism & 24 & 26 & 108 \\
\hline $\begin{array}{l}\text { Submitting project } \\
\text { ideas via the Internet }\end{array}$ & 19 & 21 & 111 \\
\hline Idea Boxes & 12 & 10 & 83 \\
\hline Public receptions & 10 & 10 & 100 \\
\hline \multicolumn{4}{|c|}{ Project selection procedures used } \\
\hline $\begin{array}{c}\text { Commissions of } \\
\text { government representatives }\end{array}$ & 46 & 46 & 100 \\
\hline $\begin{array}{l}\text { Voting in person at } \\
\text { meetings }\end{array}$ & 41 & 38 & 93 \\
\hline Another mechanism & 20 & 20 & 100 \\
\hline $\begin{array}{l}\text { Automatic project } \\
\text { evaluation based on formal } \\
\text { criteria }\end{array}$ & 18 & 16 & 89 \\
\hline $\begin{array}{l}\text { Internet voting for } \\
\text { projects }\end{array}$ & 15 & 16 & 107 \\
\hline Citizens' commissions & 9 & 15 & 167 \\
\hline Referendum & 3 & 4 & 133 \\
\hline
\end{tabular}

Source: Authors calculations based on the Report on the best practices for initiative budgeting development prepared by the Ministry of Finance of the Russian Federation (retrieved from: https://cutt.ly/LhRChMk)

In most cases, management IT systems are used as the main electronic forms in initiative budgeting, which ensure the consolidation of information on received applications and organize projects discussions in an online format, in some cases, the organization of Internet voting. In particular, online voting took place in Vladimir, Volgograd, Irkutsk, Kaliningrad, Kostroma, Kurgan, Leningrad, Novosibirsk, Sakhalin, Sverdlovsk, Tambov, Tula and Tyumen regions, Stavropol Territory, Republic of Mari El, Khanty-Mansiysk and Chukotka Autonomous Districts, as well as within the framework of municipal practices in Arkhangelsk, Samara and Orenburg regions, Yamalo-Nenets Autonomous Okrug and KhMAO.

Despite the fact that there is a gradual increase in the introduction of Internet tools, this is not enough to talk 
about the driving force of information and communication technologies in initiative budgeting.

\subsection{Assessment of electronic instruments development for compliance with the requirements of availability and evidence}

During the information collection about the initiative budgeting, the authors analyzed the government websites connected with the initiative budgeting for compliance with the requirements for availability and evidence.

- Availability of on-line information on the adopted policy in the field of initiative budgeting at the local level

It was revealed that in all regions that apply initiative budgeting, information is provided on the current legislation in this field. However, in the case when a separate portal is created for initiative budgeting, often the sites of local administrations do not provide even basic information on it, thereby making it difficult to find information for interested parties.

\section{- Access to the Internet}

From the Internet accessibility point of view, the situation looks attractive. The number of mobile broadband Internet subscribers in 2019 is estimated at $96.4 \%$, which indicates the high availability of the Internet for the population (retrieved from: www.gks.ru).

- Availability for the use of various forms of online communication, including mobile devices and platforms.

In all considered regions that have been using initiative budgeting for more than 2 years, electronic platforms for public discussions have been created. However, participants are not always active and involved. The platforms popularity depends on the convenience of the platform and the constant technical and ideological support of the platform creators. An example is the platform "Your Budget" in St. Petersburg, where the platform for project discussion was launched even before the approval of legislative norms governing the procedure for initiative budgeting projects implementation. There is an increase in the use of social networks to promote initiative budgeting and discuss projects. The most popular are Vkontakte groups and Facebook pages.

Among the promising tools for electronic participation, we should note the blockchain platforms for electronic voting, which were successfully introduced in 2019 in the Volgograd and Nizhny Novgorod regions.

Another promising application of information technologies in initiative budgeting is the use of an electronic forms for voting with verification of votes through the Unified Identification and Authentication System, which was implemented in the Sakhalin Oblast and some other regions. 103.2 million people (retrieved from: https://www.gosuslugi.ru/) are registered in this system, which is $70.3 \%$ of the total population of Russia, in this regard, this system is the most promising and reliable tool for identifying votes. Sakhalin also serves as an example, where the integration of the initiative budgeting platform (when describing projects), with departmental state procurement databases was made. This combination of information made it possible to track the stages of initiative budgeting projects implementation and to carry out purchases in relation to each project.

The prospect of initiative budgeting mechanisms further digital transformation is the creation and use of mobile applications for public participation, which will make the participation process more productive and minimize transaction and coordination costs [15].

In comparison with the requirements for availability, the requirements for evidence are not characterized by the properties of the online mechanisms themselves, but are the instrument that confirms the feasibility of the population's initiatives.

- Evidence of the connection between government decisions and participatory budgeting results

This requirement is implemented in the case when Internet platforms provide extended information about how much money is provided for the initiative budgeting projects implementation and how many projects can be implemented with this money. It also includes the ability to track the stages of projects implementation. An analysis of specialized regional websites showed that in most regions it is possible to find information only on the actual amounts of funds spent (see, e.g. the web-site of the Ministry of economic and development of Sverdlovsk region http://economy.midural.ru/content/iniciativnoebyudzhetirovanie). The ability to track projects in some regions is very well configured, for example, in the Stavropol Territory and the Sakhalin Region. In many other regions, information on the project implementation progress is not provided on the websites, and even lists of selected projects have to be looked for in the general list of adopted legislative acts of local governments, which does not help to visually confirm the effectiveness of initiative budgeting.

- Evidence of initiative groups participation in the implemented initiative budgeting projects

This requirement can be implemented through the presentation of initiative groups of ongoing projects, which can be made in the form of photo reports and lists of names. In almost all 52 regions under study, this information is absent, which indicates the lack of confirmation in this direction.

- Evidence that the public has the right to propose initiatives in the budget process

The requirement is currently being implemented mainly through the provision of open access to regulatory legal acts of both local and federal significance, 
confirming the right of the population to participate in the budget process (Murmansk, Astrakhan regions). However, the information provided in legislative acts needs to be processed and presented in a visual form, including infographic tools, which is not always used.

\section{CONCLUSION}

Currently, electronic mechanisms are the tools of multifactorial influence on the interaction between the authorities and society: they perform not only an information function, but also the ability to involve citizens in the budget process and influence the satisfaction of the population with the quality of interaction with local authorities.

As a result of the study, no direct relationship was found between the amount of funding for initiative budgeting projects and the level of electronic interaction between the authorities and society, which can be explained by the low level of electronic participation mechanisms implementation in Russian regions.

The study showed a low degree of satisfaction with the requirements of evidence, which suggests that online tools are not used as a way to increase trust between the authorities and the population. This problem can be solved by following these recommendations:

-Visually represent the rights of the population in the field of initiative budgeting on regional and local websites.

- Submit the results of initiative budgeting projects selection, as well as photo reports of implemented projects on the first pages of specialized information regional and local websites.

- Provide detailed information about initiative groups in ongoing projects.

The legislative consolidation of decision-making based on Internet voting, as well as the gradual introduction of electronic mechanisms into the discussion procedures, proves the promising role of digitalization in the development of initiative budgeting in Russia.

\section{AUTHORS' CONTRIBUTIONS}

Though the paper has been prepared by team work by the authors', Valentina Derbeneva performed the analysis and wrote the paper, Natalia Starodubets collected the data.

\section{REFERENCES}

[1] A.N. Shvetsov, From «E-government» Towards «Digital Governance»: the Meaning and Consequences of Innovations, ECO 12 (2019) 8 -26 (In Russ.). DOI: 10.30680/ECO0131-7652-2019-128-26
[2] V.V. Derbeneva, E-Participation as a Vector of Developing Participatory Budgeting, ECO 9 (2020) 90-113 (In Russ.). DOI: 10.30680/ ECO0131-76522020-9-90-113

[3] I. Shulga, L. Shilov, A. Sukhova, P. Pojarski, Can local participatory programs enhance public confidence: Insights from the local initiatives support program in Russia, Social Protection and Jobs, Discussion Paper 1931, World Bank, Washington, DC, 2019, 74 p. DOI: https://doi.org/10.1596/31810

[4] M. Naranjo-Zolotov, T. Oliveira, S. Casteleyn, Z. Irani, Continuous usage of e-participation: The role of the sense of virtual community, Government Information Quarterly 36(3) (2019) 536-545. DOI: https://doi.org/10.1016/j.giq.2019.05.009

[5] M. Naranjo- Zolotov, T. Oliveira, S. Casteleyn, Continued intention to use online participatory budgeting: The effect of empowerment and habit, in: ACM International Conference Proceeding Series, 2018, pp. 209-216. DOI: https://doi.org/10.1145/3209415.3209461

[6] R. C. Sampaio, e-Participatory budgeting as an initiative of e-requests: prospecting for leading cases and reflections on e-participation, RAP: Revista Brasileira De Administração Pública 50(6) (2016) 937-958. DOI: https://doi.org/10.1590/00347612152210

[7] S.A. Barros, R.C. Sampaio, Do Citizens Trust Electronic Participatory Budgeting? Public Expression in Online Forums as an Evaluation Method in Belo Horizonte, Policy and Internet 8(3) (2016) 292-312. DOI: https://doi.org/10.1002/poi3.125

[8] F. Muthomi, K. Thurmaier, Participatory Transparency in Kenya: Toward an Engaged Budgeting Model of Local Governance, Public administration review (2020). DOI: https://doi.org/10.1111/puar.13294.Available at https://onlinelibrary.wiley.com/doi/abs/10.1111/puar .13294

[9] L. Kipenis, D. Askounis, Assessing e-participation via user's satisfaction measurement: the case of Our Space platform, Annals of Operations Research 247 (2) (2016) 599- 615. DOI: 10.1007/s10479-0151911-8

[10] A. R. Mærøe, A. Norta, V. Tsap, I. Pappel, Increasing citizen participation in e-participatory budgeting processes, Journal of Information Technology and Politics (2020) 1-23. DOI: https://doi.org/10.1080/19331681.2020.1821421 
[11] E.A. Kapoguzov, S.A. Revyakin, Electronic Public Participation in Russia: Technology or Institute, Solo or Duo?, ECO 12 (2019) 27-46 (In Russ.). DOI: 10.30680/ECO0131-7652-2019-12-27-46

[12] V.V. Vagin, N.A. Shapovalova, The state of initiative budgeting in the Russian Federation: new trends and development opportunities, Financial Journal 1 (2018) 110-122. DOI: https://doi.org/10.31107/2075-1990-2018-1-110-122

[13] V.V. Vagin, N.A. Shapovalova, N.V. Gavrilova, The Monitoring of Initiative Budgeting Development in Russian Regions: Methodology and Practice of Organization, Financial Journal (2) (2019) 51-64. DOI: https://doi.org/10.31107/2075-1990-2019-251-64

[14] N.V. Gavrilova, Analysis of initiative budgeting practices in Russian regions, Voprosy Ekonomiki (7) (2020) 142-155 (In Russ.). DOI: https://doi.org/10.32609/0042-8736-2020-7-142-155

[15] C. Schröder, A mobile app for citizen participation, in: ACM International Conference Proceeding Series, 2014, pp. 75-78. DOI: https://doi.org/10.1145/2729104.2729137 